\title{
Outcomes following liver transplantation for patients with alcohol-versus nonalcohol-induced liver disease
}

Dory Abosh MD ${ }^{1}$, Barry Rosser MD FRCPC ${ }^{2,3}$, Kelly Kaita MD FRCPC ${ }^{2}$, Rose Bazylewski RN ${ }^{4}$, Gerald Minuk MD FRCPC ${ }^{2,3}$

D Abosh, B Rosser, K Kaita, R Bazylewski, G Minuk. Outcomes following liver transplantation for patients with alcoholversus nonalcohol-induced liver disease. Can J Gastroenterol 2000;14(10):851-855.

OBJECTIVE: To document and compare the outcomes of adult patients who received liver transplants for alcohol- and nonalcohol-induced liver diseases who attended a liver transplantation follow-up clinic in an urban, nontransplantation centre at a time when no formal alcohol abuse program for transplant candidates and/or recipients was offered.

PATIENTS AND METHODS: The study population comprised 10 alcoholic patients and 48 nonalcoholic patients followed for an average of 41 months (range five to 79 months) and 46 months (range two to 116 months), respectively. Primary outcome variables included rates of recidivism, duration of abstinence after transplantation and compliance with post-transplant medical follow-up visits. Time to discharge after transplantation, episodes of graft rejection, liver and renal biochemical abnormalities, diabetes, hypertension, sepsis, strictures, complications unrelated to transplantation and changes in psychosocial status were secondary outcome variables.

RESULTS: Significant differences were found with respect to a higher incidence of recidivism (50\% for alcoholic patients compared with $2 \%$ for nonalcoholic patients, $\mathrm{P}<0.0001$ ), a shorter period of abstinence after transplantation $(14.7 \pm 17.2$ months for alcoholic patients compared with $26.3 \pm 23.0$ months for nonalcoholic patients, $\mathrm{P}<0.05)$ and more missed office visits $(2.7 \pm 3.5$ for alcoholic patients compared with $1.0 \pm 1.9$ for nonalcoholic patients, $\mathrm{P}=0.05)$ in the alcoholic group. The alcoholic group also had a lower incidence of rejection episodes ( $10 \%$ for alcoholic patients compared with $44 \%$ for nonalcoholic patients, $\mathrm{P}<0.05$ ) but higher rates of post-transplantation diabetes ( $40 \%$ for alcoholic patients compared with $2 \%$ for nonalcoholic patients, $\mathrm{P}<0.05)$, more nontransplantation-related complications $(20 \%$ for alcoholic patients compared with $0 \%$ for nonalcoholic patients, $\mathrm{P}<0.05)$, and higher serum creatinine but lower bilirubin and cyclosporine A levels $(\mathrm{P}<0.05$, respectively). Marital separations were also more common in the alcoholic group (20\% for alcoholic patients compared with $0 \%$ for nonalcoholic patients, $\mathrm{P}<0.05)$.

CONCLUSIONS: In the absence of formal alcohol abuse programs, the post-transplantation outcome in alcoholic patients generally does not compare well with that of patients who undergo transplantation for nonalcohol-related liver diseases.

Key Words: Alcohol; Liver; Liver disease; Liver transplants; Recidivism; Transplantation

\section{Résultats de la greffe du foie chez les patients souffrant de maladie hépatique d'origine éthylique vs non éthylique}

OBJECTIF : Documenter et comparer les résultats des greffes de foie effectuées chez des patients adultes atteints de maladie hépatique d'origine éthylique ou non éthylique dans une clinique urbaine de suivi des greffés du foie (hors de centres où s'effectuent les greffes) à un moment où aucun pro-

voir page suivante

${ }^{1}$ Department of Medicine, University of Toronto, Toronto, Ontario; and Liver Diseases Unit, ${ }^{2}$ Departments of Medicine, ${ }^{3}$ Pharmacology and

${ }^{4}$ Nursing, University of Manitoba, Health Sciences Centre, Winnipeg, Manitoba

Correspondence and reprints: Dr GY Minuk, Liver Diseases Unit, Room 803F-715 McDermot Avenue, Winnipeg, Manitoba R3E 3P4. Telephone

204-789-3204, fax 204-789-3971, e-mail gminuk@cc.umanitoba.ca

Received for publication August 1, 1999. Accepted September 1, 1999 
gramme anti-alcoolisme n'était offert aux candidats ou aux receveurs de greffes.

PATIENTS ET MÉTHODES : La population de l'étude comprenait dix patients alcooliques et 48 non-alcooliques suivis en moyenne pendant 41 mois (de cinq à 79 mois) et 46 mois (de 2 à 116 mois), respectivement. Les variables pronostiques principales étaient les taux de récidive, la durée de l'abstinence après la transplantation et la fidélité aux visites de suivi médical suivant la greffe. Les variables pronostiques secondaires étaient le temps nécessaire à l'obtention du congé post-transplantation, les épisodes de rejet de la greffe, les anomalies biochimiques, hépatiques et rénales, le diabète, l'hypertension, la septicémie, les strictures, les complications indépendantes de la transplantation et les changements affectant le statut psychosocial.

RÉSULTATS : Des différences significatives ont été observées en ce qui a trait à l'incidence plus élevée de récidive dans le groupe des sujets alcooliques $(50 \%$ chez les alcooliques vs $2 \%$ chez les non-alcooliques, $p<0,0001$ ), la période plus brève d'abstinence après la transplantation
$(14,7 \pm 17,2$ mois chez les alcooliques vs $26,3 \pm 23,0$ mois chez les non-alcooliques, $p<0,05)$ et le plus grand nombre de rendez-vous manqués $(2,7 \pm$ $3,5$ chez les alcooliques vs $1,0 \pm 1,9$ chez les non-alcooliques, $p=0,05)$. Le groupe alcoolique a par contre présenté une incidence moindre rejets ( $10 \%$ chez les alcooliques vs $44 \%$ chez les non-alcooliques, $p<0,05$ ), mais des taux plus élevé de diabète post-greffe ( $40 \%$ chez les alcooliques vs $2 \%$ chez les non-alcooliques, $p<0,05)$, un plus grand nombre de complications indépendantes de la transplantation ( $20 \%$ chez les alcooliques vs $0 \%$ chez les non-alcooliques, $p<0,05)$ et des taux de créatinine sérique plus élevés et de bilirubine et de cyclosporine A plus bas ( $p<0,05$ respectivement). Les séparations ont également été plus fréquentes dans le groupe des alcooliques ( $20 \%$ chez les alcooliques contre $0 \%$ chez les non-alcooliques, $p<0,05)$.

CONCLUSION : En l'absence de programmes contre l'alcoolisme, les résultats d'une greffe hépatique sont moins bons chez les patients alcooliques que chez les patients qui subissent une transplantation pour une maladie hépatique qui n'est pas d'origine éthylique.
A lcohol-induced liver disease is a common cause of liver failure (1). Although some improvements have been made in the management of this condition, liver transplantation is the only curative treatment for end-stage disease. However, concerns regarding the rate of recidivism have limited the number of transplantations that are performed in alcoholic patients. Recent reports suggesting that recidivism rates may not be as high as originally anticipated have resulted in renewed interest in the issue of liver transplantation for alcohol-induced liver disease (2-9).

Policies and guidelines for performing liver transplantations in patients with alcohol-induced liver disease should be based on data not only from alcoholic patients with strong supportive environments in selected centres where attendance in formal alcohol abuse programs is compulsory, but also from alcoholic patients in centres where such support systems may not be in place. In the present study, we report the outcome of liver transplantations in alcoholic patients in whom limited perioperative and no long term, formal counselling for alcoholism was offered. We also compared the outcomes in these patients with those of patients who received transplants for nonalcohol-induced forms of liver disease.

\section{PATIENTS AND METHODS}

Study population and protocol: Fifty-eight patients who underwent liver transplantation between January 1, 1987 and January 1, 1997 for end-stage, acute or chronic liver disease were studied retrospectively. Patients who received transplants as children were not included in the study. Patients with nonalcoholic end-stage liver disease but with a history of concomitant alcohol abuse (eg, alcoholic patients with chronic hepatitis $\mathrm{C}$ viral infections) were classified as 'alcoholic liver transplant recipients'. All preoperative and follow-up appointments were carried out at the Liver Transplantation Follow-Up Clinic at the Health Sciences Centre, Winnipeg, Manitoba, whereas the transplantation procedures themselves were performed at various centres throughout Canada and the United States. Formal alcohol counselling was not provided before or after the operation at any of these centres. The average duration of hospitalization for transplantation was approximately four weeks (10). Follow-up visits in the Liver Transplantation Follow-up Clinic were scheduled as follows: every week for one month, every two weeks for two months, every month for one year and every three months thereafter. The status of patients before and after transplantation was documented by the clinic's transplantation nurse and clinic physician in charge. Criteria for referral to a transplantation centre for patients with alcohol-induced liver disease were acknowledgement of alcohol abuse as the cause of their liver disease, a verbal commitment to abstain from alcohol consumption before and after transplantation, consultation with and approval from a substance abuse specialist and social worker, no alcohol consumption for six months before referral for transplantation and home support deemed adequate by a social worker. Completion of a formal alcohol dependence program before and/or after transplantation was not a prerequisite for referral, nor was the patient required to sign a contract committing to abstain from alcohol.

Study end points: Primary end points of the study were rates of recidivism, period of abstinence from alcohol after transplantation and compliance with post-transplantation follow-up visits. Secondary end points were time to discharge after transplantation, episodes of graft rejection after discharge, liver enzyme abnormalities, diabetes, hypertension, sepsis, strictures, complications unrelated to transplantation and changes in psychosocial status.

Definitions: 'Alcohol-induced liver disease' was defined as liver disease with compatible liver biochemistry and/or histological findings in the setting of daily alcohol consumption of more than $60 \mathrm{~g}$ in males and $40 \mathrm{~g}$ in females for a minimum of 10 years. 'Recidivism' was defined as post-transplantation alcohol consumption in excess of two alcoholic beverages ( 20 to $30 \mathrm{~g}$ ) per day. Consumption was based on information obtained from the patient and/or collateral information supplied by the patient's family or friends. The period of abstinence after transplantation was calculated from the date of 
TABLE 1

Population demographics

\begin{tabular}{lcc}
\hline & $\begin{array}{c}\text { Alcoholics } \\
(\mathbf{n}=\mathbf{1 0})\end{array}$ & $\begin{array}{c}\text { Nonalcoholics } \\
(\mathbf{n = 4 8})\end{array}$ \\
\hline Men, n (\%) & $7(70 \%)$ & $24(50 \%)$ \\
Women, n (\%) & $3(30 \%)$ & $24(50 \%)$ \\
Age (years) & $50.0 \pm 8.1$ & $50.5 \pm 14.1$ \\
$\begin{array}{l}\text { Months of follow-up } \\
\text { (mean } \pm \text { SD) }\end{array}$ & $\begin{array}{c}41.0 \pm 25.6 \\
(\text { range 5-79) }\end{array}$ & $\begin{array}{c}45.7 \pm 36.1 \\
(\text { range 2-116) }\end{array}$ \\
\hline
\end{tabular}

the transplantation to the first consumption of any amount of alcohol. Compliance was documented by calculation of the number of 'did not appear' entries into the patient's chart for scheduled appointments. Time to discharge after transplantation was calculated from the time of transplantation to the patient's first visit at the Liver Transplantation Outpatient Clinic. Rejection was defined as any episode of right upper quadrant discomfort, fever, elevated liver enzyme concentrations and compatible liver histology requiring an increase in immunosuppressive therapy. Diabetes was diagnosed if there was a persistent increase in blood glucose levels requiring the use of oral hypoglycemic agents or insulin. Hypertension was diagnosed when systolic or diastolic blood pressures were sufficiently elevated from baseline to require the use of antihypertensive medications. 'Sepsis' was defined as culture-positive bacterial, mycobacterial, viral or fungal infections requiring the use of antimicrobial therapy or monitoring by infectious disease consultants. Biliary strictures were diagnosed if there was biochemical evidence of cholestasis and radiological imaging evidence (endoscopic retrograde cholangiograms, percutaneous transhepatic cholangiography or nuclear medicine imaging) consistent with strictures. Finally, 'complications unrelated to transplantation' were defined as any medical problem that could not be ascribed to either the procedure and/or the immunosuppressive therapy associated with transplantation, requiring unscheduled visits to the clinic.

Statistical analysis: ANOVA followed by a Student's $t$ test was used for parametric data, and a Fisher's exact test was used for nonparametric data where appropriate. The results provided represent the mean $\pm S D$, unless otherwise stated. $\mathrm{P}<0.05$ was considered significant.

\section{RESULTS}

Of the 58 patients followed at the Liver Transplantation Follow-Up Clinic, 10 had received transplants for alcoholinduced liver failure. One patient also had a coexisting chronic hepatitis $\mathrm{C}$ virus infection. Of the remaining 48 nonalcoholic patients, causes of liver failure were primary biliary cirrhosis $(n=14)$, primary sclerosing cholangitis $(n=12)$, hepatitis $C$ viral infections $(n=7)$, autoimmune hepatitis $(n=5)$, cryptogenic cirrhosis $(n=5)$ and miscellaneous causes (unexplained fulminant hepatic failure, Wilson's disease, cholestasis, Budd-Chiari syndrome and hepatitis B $[\mathrm{n}=5])$.
TABLE 2

Primary outcome variables

\begin{tabular}{lccc}
\hline & $\begin{array}{c}\text { Alcoholics } \\
(\mathbf{n = 1 0})\end{array}$ & $\begin{array}{c}\text { Nonalcoholics } \\
(\mathbf{n = 4 8})\end{array}$ & $\mathbf{P}$ \\
\hline $\begin{array}{c}\text { Excessive alcohol consumption } \\
\quad \text { (after transplantation), } \mathrm{n}(\%)\end{array}$ & $5(50 \%)$ & $1(2 \%)$ & 0.0001 \\
$\begin{array}{c}\text { Months of abstinence from } \\
\quad \text { alcohol (mean } \pm \text { SD) }\end{array}$ & $14.7 \pm 17.2$ & $26.3 \pm 23.0$ & 0.02 \\
$\begin{array}{c}\text { Compliance (number of 'no } \\
\text { shows') (mean } \pm \text { SD) }\end{array}$ & $2.7 \pm 3.6$ & $1.0 \pm 1.9$ & 0.05 \\
\hline
\end{tabular}

The mean age of the alcoholic patients at the time of transplantation was similar to that of the nonalcoholic patients $(50.0 \pm 8.1$ years compared with $50.5 \pm 14.1$ years [Table 1]). Seven of the 10 (70\%) alcoholic patients were male compared with 24 of the 48 (50\%) nonalcoholic patients $(\mathrm{P}=0.2)$. The mean duration of follow-up was 41 months (range five to 79 months) for alcoholic patients and 46 months (range two to 116 months) for nonalcoholic patients.

With respect to primary outcome variables (Table 2), five of $10(50 \%)$ alcoholic patients and one of $48(2 \%)$ nonalcoholic patients consumed excess alcohol (recidivism) $(\mathrm{P}<0.0001)$. The average period of abstinence from alcohol consumption was $14.7 \pm 17.2$ months for alcoholic patients compared with $26.3 \pm 23.0$ months for nonalcoholic patients $(\mathrm{P}=0.02)$. Alcoholic patients failed to appear for clinic appointments more often than nonalcoholic patients $(2.7 \pm 3.6$ compared with $1.0 \pm 1.9$ missed visits, respectively, $\mathrm{P}=0.05$ ).

The results of the secondary outcome variables are given in Table 3. The following differences between alcoholic and nonalcoholic patients, respectively, were significant: acute rejection episodes (one in 10 [10\%] compared with 21 of 48 [44\%], $\mathrm{P}<0.05$ ), development of diabetes (four of 10 [40\%] compared with one in 48 [2\%], $\mathrm{P}<0.005)$, complications unrelated to the transplant (two in 10 [20\%] versus zero in 48 $[0 \%], \mathrm{P}<0.05)$, average creatinine concentration in the first six months after transplantation $(156 \pm 51 \mu \mathrm{mol} / \mathrm{L}$ compared with $103 \pm 36 \mu \mathrm{mol} / \mathrm{L}, \mathrm{P}<0.05)$, average total bilirubin concentration beyond six months after transplantation $(15.5 \pm 5.1 \mu \mathrm{mol} / \mathrm{L}$ compared with $24.2 \pm 17.9 \mu \mathrm{mol} / \mathrm{L}$, $\mathrm{P}<0.05)$ and average cyclosporine $\mathrm{A}$ level beyond six months after transplantation $(256 \pm 67 \mu \mathrm{mol} / \mathrm{L}$ compared with $304 \pm 121 \mu \mathrm{mol} / \mathrm{L}, \mathrm{P}<0.005)$. Two alcoholic patients (20\%) separated from their spouses during the posttransplantation follow-up period compared with none of the $36(0 \%)$ nonalcoholic patients who had spouses $(\mathrm{P}<0.05)$. No significant differences occurred with respect to the other secondary outcome variables.

\section{DISCUSSION}

The results of our study are not surprising in that, intuitively, one would predict that if recidivism rates are high in carefully screened patients who have undergone formal pretransplantation psychosocial evaluations and post-transplantation counselling, then those rates would be even 
TABLE 3

Secondary outcome variables

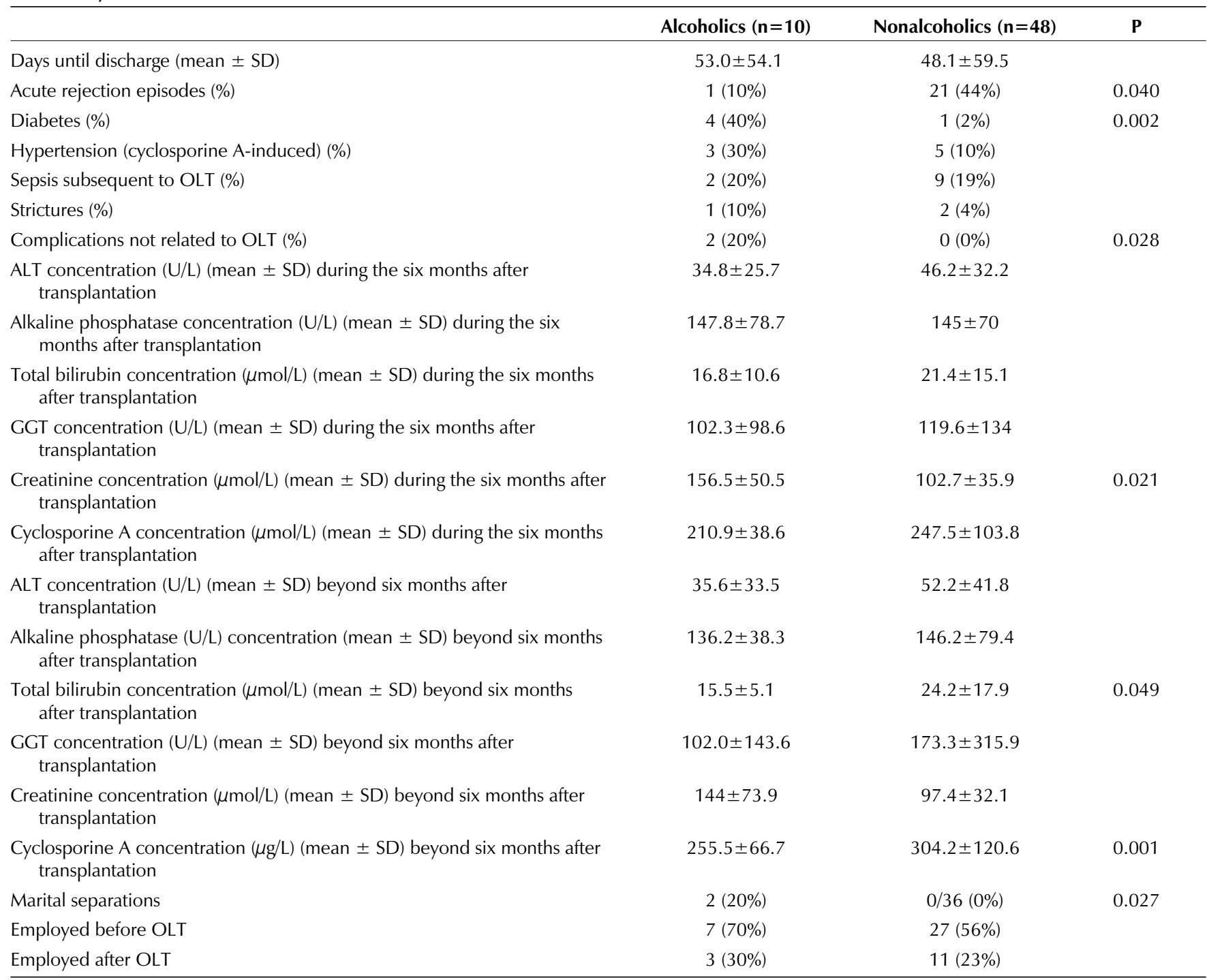

ALT Alanine aminotransferase; GGT Gamma-glutamyl transferase; OLT Orthotopic liver transplantation

higher in patients with no such formal interventions. Thus, the recidivism rate of $50 \%$ in our patients is in keeping with the rates of $13 \%$ to $34 \%$ reported by others (2-9). A higher recidivism rate (19 of 20 patients) has been reported in only one other study, despite that formal pre- and posttransplantation counselling were provided in that study population (11). The higher recidivism rate in the latter study was ascribed to interviews being conducted by interviewers independent of the transplantation group. Whether a similar approach would have resulted in even higher rates in our patient population remains to be determined. While it could be argued that the high rates identified in our study might have resulted from relatively long follow-up times, our mean follow-up time of 41 months was well within the 21 to 78 months reported by other investigators (2-9).

As in other studies, we found that recidivism tended to occur beyond one year after transplantation. In the past, this finding was used to explain why rejection episodes were similar in alcoholic and nonalcoholic transplant recipients because the majority of rejection episodes tended to occur within three months of transplantation. However, we found fewer episodes of rejection in the alcoholic group than in the nonalcoholic group (10\% compared with $44 \%$, respectively), despite the late onset of recidivism. Perhaps the small number of alcoholic patients in our study contributed to this finding, but others have described similar results (12). Of course, the mechanism whereby alcoholic patients might have a lower incidence of rejection in this setting has yet to be determined.

The higher rates of post-transplant diabetes in alcoholic patients has not been described previously but may relate to the adverse effects of alcohol on the pancreas (either pre- or post-transplantation). The adverse effects of alcohol on other tissues may also explain the higher incidence of com- 
plications unrelated to transplantation (13). Although the lower bilirubin levels in alcoholic patients may reflect the lower cyclosporine levels observed in this group, the reason for the higher creatinine levels in alcoholic patients is unclear. Unfortunately, the retrospective design of this study precluded performing the additional investigations required to explain these findings.

Two of the 10 alcoholic patients (20\%) in our study separated from their spouses after transplantation. While statistically significant compared with nonalcoholic patients $(\mathrm{P}<0.05)$, the small numbers of alcoholic patients must be considered when interpreting this finding. Because the decline in employment after transplantation was similar between the two groups (40\% in alcoholic patients and 33\% in nonalcoholic patients), it can be argued that alcoholic patients do not have a higher incidence of post-transplantation psychosocial disturbances than nonalcoholic patients.

\section{CONCLUSIONS}

We described and compared the outcomes of patients who received liver transplants because of alcohol-induced liver disease with patients who received liver transplants because of nonalcohol-related liver failure and found significant differences; some differences were beneficial but most were detrimental to the group with alcohol-induced liver disease. Because of these findings, we have instituted more formal and rigorous preoperative selection, and postoperative counselling and care for this patient population.

\section{REFERENCES}

1. Byron D, Minuk GY. Clinical hepatology: profile of an urban, hospital-based practice. Hepatology 1996;24:813-5.

2. Raakow R, Langrehr J, Lohmann R, et al. Is orthotopic liver transplantation for end stage alcoholic cirrhosis justified? Transplant Proc 1995;27:1241-2.

3. Osorio RW, Ascher NL, Avery M, Bacchetti P, Roberts JP, Lake JR. Predicting recidivism after orthotopic liver transplantation for alcoholic liver disease. Hepatology 1994;20:105-10.

4. Berlakovich G, Steininger R, Herbst F, Barlan M, Mittlbock M, Muhlbacher F. Efficacy of liver transplantation for alcoholic cirrhosis with respect to recidivism and compliance. Transplantation 1994;58:560-4.

5. Sherman D, Williams R. Liver transplantation and the alcoholic patient. Alcohol Alcohol 1995;30:141-3.

6. Starzl T, Van Thiel D, Tzakis A, et al. Orthotopic liver transplantation for alcoholic cirrhosis. JAMA 1988;260:2542-5.

7. Lucey M, Merion R, Henley K, et al. Selection for and outcome of liver transplantation in alcoholic liver disease. Gastroenterology 1992;102:1736-41.

8. Kumar S, Stauber R, Gavaler J, et al. Orthotopic liver transplantation for alcoholic liver disease. Hepatology 1990;11:159-64.

9. Gish R, Lee A, Keefe E, Rome H, Concepcion W, Esquivel C. Liver transplantation for patients with alcoholism and end stage liver disease. Am J Gastroenterol 1993;88:1337-42.

10. Bazylewski R, Rosser BG, Cohen A, Kaita KDE, Minuk GY. Profile of a liver transplant follow-up clinic in a nontransplant Canadian urban centre. Can J Gastroenterol 1997;11:235-8.

11. Howard L, Fahy T, Wong P, Sherman D, Gane E, Williams R. Psychiatric outcome in alcoholic liver transplant patients. Q J Med 1994;87:731-6.

12. Bonet H, Gavaler JS, Wright HS, et al. The effect of continued alcohol use on allograft rejection following liver transplantation for alcoholic liver disease. Gastroenterology 1993;104:878A. (Abst)

13. Lucey MR, Carr K, Beresford TP, et al. Alcohol use after liver transplantation in alcoholics: a clinical cohort follow up study. Hepatology 1997;25:1223-7. 


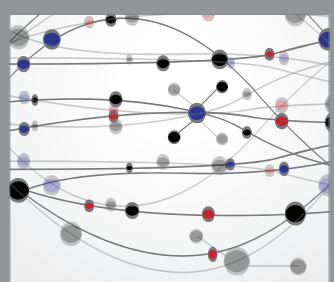

The Scientific World Journal


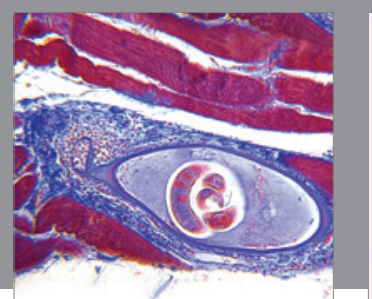

Gastroenterology Research and Practice

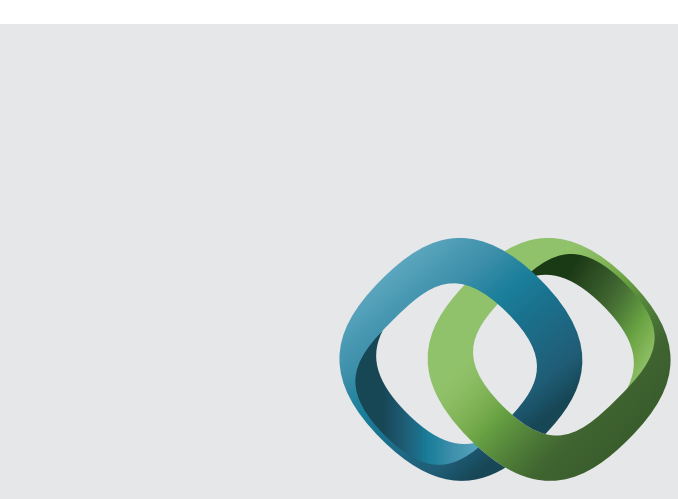

\section{Hindawi}

Submit your manuscripts at

http://www.hindawi.com
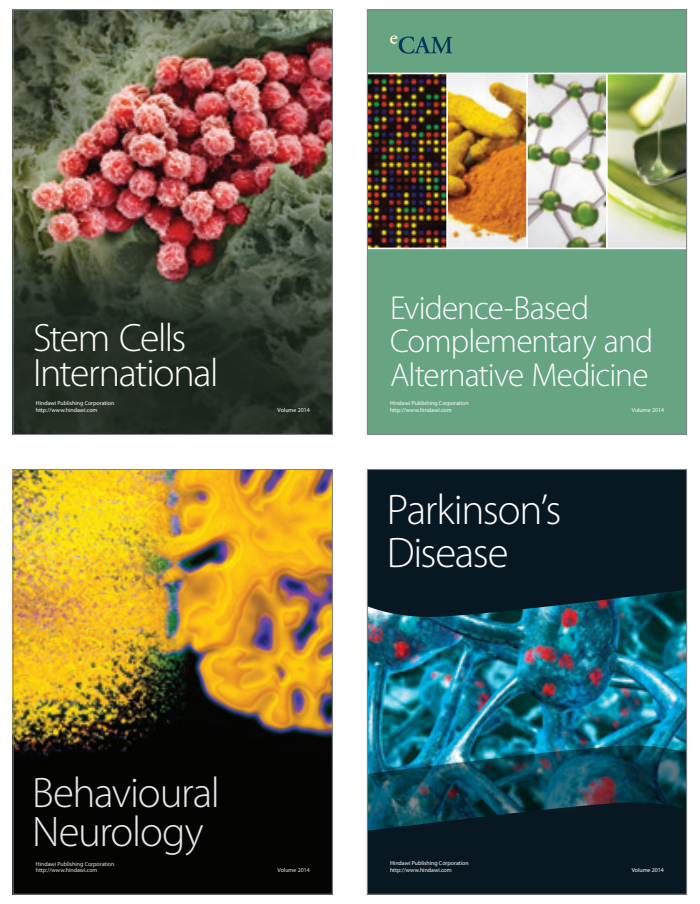
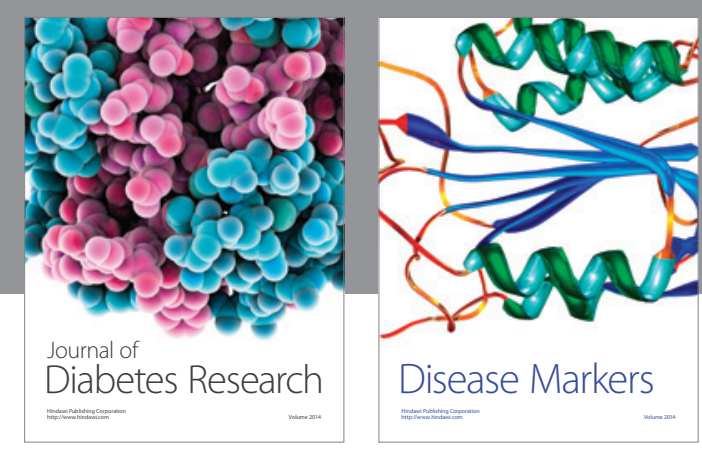

Disease Markers
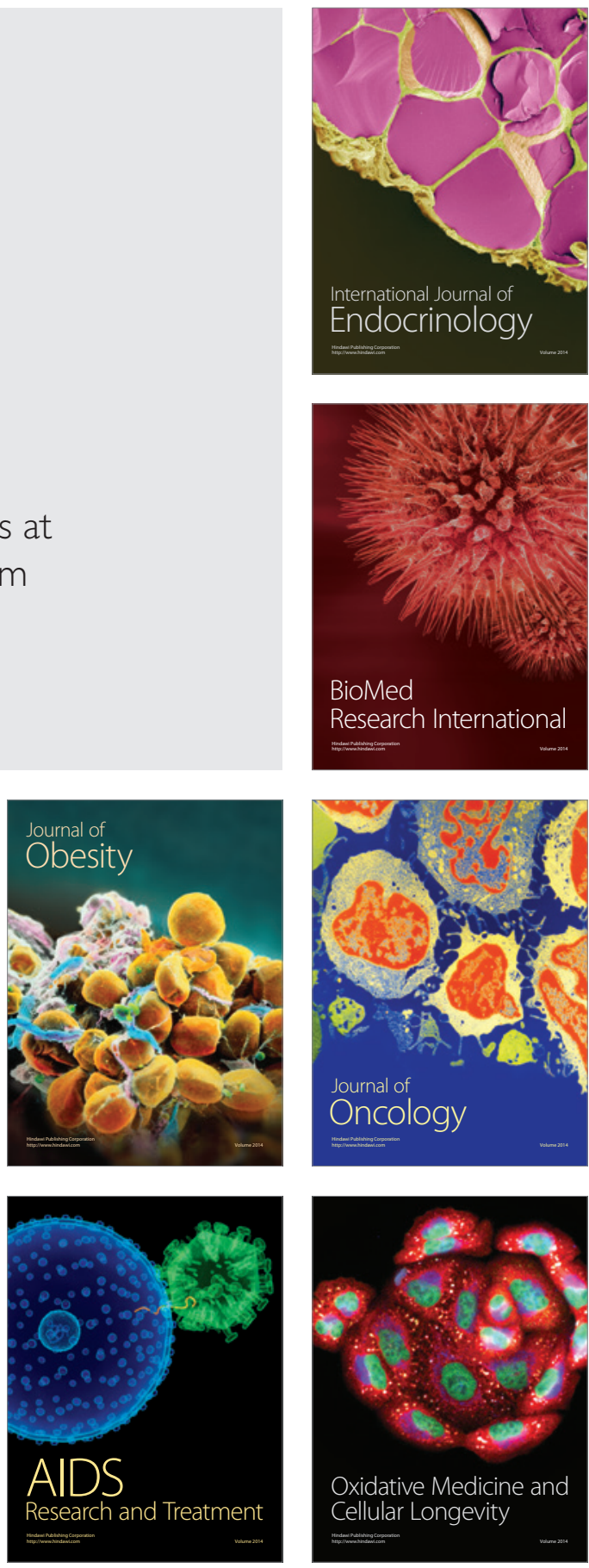